\title{
Trade Liberalization and Trade Flows in Nigeria: An Aggregated Analysis
}

\author{
Anionwu, Carol Ph.D \\ Department of Business Administration, Faculty of Management Sciences, \\ Cross River University of Technology, Nigeria
}

\section{ABSTRACT}

This study examines the impact of trade liberalization and trade flows in Nigeria using an econometric regression model of the Ordinary Least Square (OLS). From the result of the OLS, it is observed that trade flows and export subsidies have a positive relationship with economic growth. This means that when trade flows and export subsidies are increasing, it will bring about more growth in Nigerian economy. On the other hand, import tariffs, import quotas and export taxes have a negative impact on economic growth in Nigeria. This means that if import tariffs, import quotas and export taxes are falling, there will be increase in economic growth. From the empirical work reviewed, some authors argued that trade liberalization and trade flows is positively related to economic growth; while some authors argued that it is negatively related. The findings of the study also show that trade flows, import tariffs, import quotas and export taxes are statistically significant in explaining the Nigerian economy while export subsidy is statistically insignificant. The study therefore recommends that government should encourage import liberalization through reduction in tariff rates, gradual removal of Non-Tariff Barriers (NTB), outright banning of certain goods which will ensure that our imports, following trade liberalization, is directed mainly on intermediate and capital goods. Imports of consumables would be brought to nil and therefore there would be a corresponding increase in the production of competitive import. Finally, the government should vigorously seek to improve the international stand of the economy with other economies of the world so as to enlarge the market for Nigerian exports. It should also re-orient its policy towards the external sector and ensure that the sector contribute optimally to output growth.

\section{INTRODUCTION}

Trade liberalization and flows within and outside an economy has been a subject of discussion and research among scholars and researchers alike for over seven decades. The idea that trade liberalization or trade openness is one of the most important determinants of economic growth is becoming increasingly popular among governments of less developed countries (LDCS) and Nigeria in particular. Conventional wisdom suggests that openness promotes economic growth. However, while various theoretical models predict that openness to international trade accelerates economic growth, the empirical evidence has been mixed or imprecise (Eleanya, 2013). According to Echekoba, Okonkwo and Adigwe (2015), trade liberalization started in 1947, after the 2nd World war, with the inception of the General Agreement on Tariffs and Trade (GATT). The GATT was negotiated in 1947 by 23 countries of which 12 are industrialized countries and 11, developing countries. The main focal point of the GATT was to lower trade barriers. GATT was later replaced by the WTO (World Trade Organization) in 1994. Basically, the main purpose of trade liberalization is to allow countries to export those goods and services that they can produce efficiently, and import the goods and services that they produce inefficiently. Sequel to the emergence of trade liberalization and trade flows among various economies, argued that trade liberalization aids growth, which in turn aids poverty alleviation, but adds that trade policy, should not none the less, be manipulated too closely with an eye to direct poverty consequences. It should rather be set on a sound basis over-all (Ijeoma, 2013; Winters, 2002).

Despite the efforts of successive governments in Nigeria in liberalizing trade and its flows in order to 
enhance the economy, there is a persistent rise in the poverty level, business failures and the economy plunging into recession in recent time. According to Umoru (2013), In Nigeria, despite the implementation of trade liberalization measures and despite the persistent signs of economic recovery as seen from reduction in external debt and debt service payment, some macroeconomic indicators show poor performances of the overall economy. For instance, the economy has been characterized by low degree of savings accompanied by liquidity trap, capacity underutilization and low rate of capital formation. This poor situation reflects more the rate of unemployment in the country. The conventional arguments in support of and against international trade are no doubt convincing, but the empirical evidence is yet to be typical especially in Nigeria. Trade liberalization is an essential component of international trade and finance. It entails the removal of the various barriers to trade that countries around the world have erected and has been recognized by many studies as an important factor accounting for the economic growth and development of many Nations (Echekoba, Okonkwo, \& Adigwe, 2015). Trade liberalization has been a burning issue in Nigeria ascertaining whether Nigeria's involvement 0 in international trade boosts or hinders economic growth has been a persisting problem thus, warranting an empirical investigation into the study area to ascertain the impact of trade liberalization and trade flows on growth in Nigerian

\section{Objectives of the study}

The broad objective of the study is to examine the impact of trade liberalization and trade flows on Nigerian economic growth from 1980 to 2017. Specifically, the study seeks to examine the impact of trade openness, import tariffs, import quotas, export taxes and export subsidies on economic growth in Nigeria

\section{Hypotheses}

Ho1: Trade openness, import tariffs, import quotas, export taxes and export subsidies have no significant impact on economic growth in Nigeria.

\section{Empirical literature}

The study has examined some related empirical literature on trade liberalization and trade flows. For example: Ejike, Anah \& Onwuchekwa (2018) examined the effect of trade liberalization on economic growth in Nigeria, using the Gross domestic product (GDP) as proxy for economic growth. The study made use of set of data that spanned (1980 2015). Ordinary Least Squares (OLS) was used in estimating the effect of trade liberalization on economic growth in Nigeria with a view to ascertaining whether long-run relationship exists between the two and also used in verifying for structural change that may have occurred within the implementation period of a free trade regime that started in 1986. Data for the study were sourced from World Development Indicators (WDI) of the World Bank and Statistical Bulletin of the Central Bank of Nigeria (CBN) various issues. Results indicate that liberalization has positive and significant effect on economic growth in Nigeria, with an evidence of a long-run relationship. Similarly, strong evidence was found to support structural change that took place in 1986 when free trade policy was adopted. The results also presented a violation of the a priori in the case of export and import which showed negative and positive signs respectively. Ojeyinka and Adegboye (2017) examined the impact of trade liberalization on performance in the Nigerian economy, with special reference to agricultural and manufacturing sectors. Simultaneous models were developed to capture the joint effects of trade liberalization on the two sectors. The Generalized Method of Moment technique was used to estimate the role of trade liberalization on the performance of the selected sectors. The study shows a significant positive impact of trade liberalization on the output of agricultural sector while a negative but significant relationship exists between measures of trade liberalization and manufacturing output in Nigeria. The study also reveals that exchange rate exerts a positive but insignificant impact on agricultural output while the effect of inflation on agricultural output is positive and significant within the study period. Unlike the agricultural output, both exchange rate and inflation have negative impact on manufacturing sector's output. Moreover, finding from the study also confirmed the possibility of substantial economic linkage between the two sectors, as their magnitudes were positive and significant which suggests some significant level of interdependence between them in the Nigerian economy. Afolabi, Danladi and Azeez (2017) examined the impact of international trade on economic growth in Nigeria, with the objective of identifying the major factors influencing economic growth through international trade using time series secondary data obtained from Central Bank of Nigeria, National Bureau of Statistics and 
International Financial Statistics for a period between 1981 and 2014. Augmented Dickey-Fuller (ADF) test together with Phillip- Perron (PP) test of Unit Root Tests were employed to ascertain the stationarity properties of the variables. The Ordinary Least Square (OLS) technique was used to test for the significant relationship between the level of economic growth proxied by GDP as dependent variable and exchange rate, government expenditure, interest rate, foreign direct investment, import and export as independent variables. The result revealed that government expenditures, interest rate, import and export are all positively significant while exchange rate and foreign direct investment are negatively insignificant to the growth process of the Nigerian Economy. Nwinee and Olulu-Briggs (2016) examined trade openness, financial development, and the Nigerian economy. The aim was to investigate the relationship between changes in different variables of trade openness and financial development; and its impact on the growth rate of the Nigerian economy using annual time series data for the period 1981-2013from the Central Bank of Nigeria to estimate both long and short-run relationship as well as causal effects. The Unit root test shows that the variables were stationary at level and after being first differenced; at the $5 \%$ significance level. The Johansen Co integration test gave evidence of four co-integrating equations which explains that a long-run equilibrium relationship exist among the variables. The Vector Error Correction Model was used to analyze short-run adjustment dynamics and showed $96.7 \%$ speed of adjustment of prior deviations from equilibrium. The Granger Causality test demonstrated both bi-directional causality between real effective exchange rate and total trade; and uni-directional causality from gross domestic product to total trade, gross domestic product to credit to the private sector, total trade to foreign direct investment, total trade to credit to the private sector and real effective exchange rate to foreign direct investment. Furthermore, the Impulse Response and Variance Decomposition test indicate both positive and negative shocks which are consistent with our findings from the vector error correction model and Granger causality analysis. Overall, all the results obtained are in line with apriori expectations. Adeleye, Adeteye and Adewuyi (2015) examined the impact of international trade on economic growth in Nigeria (1988-2012) using net export (i.e total export less total import) and Balance of Payment as proxies for international trade while Gross Domestic Product represent economic growth.
The study employed regression analysis as the method of analysis using co-integration and error correction modeling techniques to find the long-run relationship between economic performance and international trade. Only Total Export (TEX) remains positive and significant while others remain insignificant, which means, Nigeria is running a monocultural economy where only oil act as the sole support of the economy without tangible support from other sectors such as industrial/manufacturing and agriculture. Echekoba, Okonkwo and Adigwe (2015) investigated trade liberalization and economic growth: The nigerian experience (1971-2012) using Ordinary Least Squares (OLS) regression technique. The results provided clear indication that imports and exports significantly and positively affect economic growth in Nigeria. Olaifa, Subair and Biala (2015) adopts the ordinary least squares in estimating the influence of trade liberalization on economic growth in Nigeria between 1970 and 2012 with a view to examining whether a long term relationship exists between the two and also to check for structural change that may have occurred with the implementation of a free trade regime in 1986.Trade liberalization was conceived as openness and proxied as the ratio of total trade to GDP. Time series data sourced from the World Development indicator (WDI) of the World Bank and the Central Bank of Nigeria (CBN) statistical bulletin and annual reports were analysed. Result shows that liberalization supports economic growth in Nigeria with an evidence of a long run relationship. Strong evidence was found to support a structural change taking place in 1986 with the adoption of free trade policy. However export was reported to be negatively related to growth. Ude and Agodi (2015) empirically examined whether trade openness makes sense, using Nigeria trade policy as yardstick. Considering the framework of the traditional trade theories which postulate that trade has positive impact on economic growth, the study employed Autoregressive Conditional Heteroscedasticity (ARCH), Generalized Autoregressive Conditional Heteroscedasticity (GARCH) and Pairwise-Granger causality methodology using secondary data from 1984 to 2013. Results show that trade openness has a significant impact on economic growth. This implies that trade openness make sense in Nigeria given that most of the period under investigation ranged from when Nigeria adopted unrestricted trade policies. The control variables (interest rate and exchange rate) have significant positive effect on economic growth in Nigeria. The pairwise Granger causality test shows 
that there is a unidirectional causality between economic growth and trade openness at lag one only. Azeez, Dada and Aluko (2014) examined the effect of international trade on the economic growth of Nigeria in the 21 st century using an annual time-series data from 2000-2012 and the Ordinary Least Square (OLS) estimation technique. Variables of the model specified economic growth as measured by gross domestic product which is dependent on international trade proxy by imports, exports, and trade openness. It was evidenced that international trade has a significant positive impact on economic growth. Imports, Exports, and Trade Openness have significant effect on the economy. Akinyemi, Ebiefie, Tinuola, Adekojo \& Ibiyemi (2014) investigated the relationship between trade liberalization and employment generation in Nigeria using secondary data on the quoted variables for the period 2003-2007. Panel regression model (Pooled Least Squares) was employed to examine the nexus between trade liberalization and employment generation. The study found that employment generation as result of trade liberalization the key determinant is tariff structure as a percentage increase will generate $73.4 \%$ of employment while other variables (wages, openness and FDI) effect on employment is not much. Also, the cumulative significant of the study shows that trade tariffs, wage rate, openness, and foreign direct investment have simultaneous significant effect on employment rate in the Nigeria's manufacturing, transport, agriculture and mining and quarrying sectors. Monisola (2014) examined public policy and trade liberalisation in Nigerian economic development. The study considered the components of the trade policy such as trade openness, privatization, investment flow and import tariffs with a view to assess the impacts of some of those policy prescriptions on Nigerian economic development. Secondary data was utilized to descriptively analyze the impacts of trade liberalization policy on Nigeria economic development. The result showed that trade liberalization policy has not had a positive impact on Nigeria economic development. Eleanya (2013) investigated openness and economic growth in Nigeria using regression model of the ordinary Least Squares (OLS) technique and data from 1970 - 2008 from CBN statistical bulletin, 2008 were employed. GDP (Economic Growth) is the dependent variable, whereas degree of openness, investment, government expenditure and lagged GDP are the independent variables. The independent variables have direct impact on the economic growth respectively. The results show that, a unit increase in the degree of openness holding other variables constant, leads to about 5 percent increase in GDP; 1 percent increase in investment holding other variables constant, leads to about 18 percent increase in GDP; 1 percent increase in government expenditure given other variables, leads to about 9.7 percent increase in GDP and 1 percent increase in previous GDP given other variables, leads to about 100 percent increase in the current GDP. It also shows adjusted R2 of 0.99 . The unit root tests show that all the variables, but lagged GDP are stationary only after first difference, and the cointegration test shows that there exists long run equilibrium between economic growth, trade openness, investment, and government expenditure in Nigeria. The study reveals that openness impact significantly on economic growth in Nigeria. Umoru (2013) examined employment and international trade flows in Nigeria within the framework of the vector error correction model. The study found that the volume of international trade has no significant positive impact on employment generation in Nigeria. Indeed, the recent empirical evidence is that of a significant negative employment effect of total trade volume in Nigeria. Besides, the employment effect of trade liberalization is insignificant and negative in this study. Soi (2013) assessed the impact of international trade on economic growth in Kenya with the years under consideration being 1960 to 2010. The study specifically examined the effect of exchange rate, inflation and final government consumption on Kenyan economic growth using World Bank data for these variables. The multiple linear regression model and Barro growth model were used to estimate the existing the relationship between variables then ordinary least square method was applied. From the findings, Exchange rate has no effect on GDP growth rate, while inflations had negative and significant effect on GDP growth rate. Final government consumption had positive effect on GDP growth rate in Kenya. Umoru (2013) investigated the relation between trade liberalization and industrial growth in Nigeria using the human capital model of endogenous growth with modifications for trade liberalization within the Nigerian context which was estimated using an error correction model [ECM]. The empirical findings in this study have it that there is a positive and significant correlation between trade liberalization and industrial growth in Nigeria, structural deregulation had positive impact industrial growth in Nigeria, Nigerian industries are labour intensive, industrial production responded negatively 
and insignificantly to capital formation in Nigeria, industrial growth is cumulative and self-sustaining in Nigeria. The result however does not provide evidence of significance of structural deregulation over the period of short-run analysis. Nageri, Ajayi, Olodo and Abina (2013) carried out an empirical study of growth through trade in Nigeria using multiple econometric regression models of the Ordinary Least Square (OLS). The finding shows that trade contribute positively to economic growth but Nigeria's trade policies, and implementation is still not growth friendly. Umoru and Oseme (2013) investigated trade flows and exchange rate shocks in Nigeria by adopting the vector error correction methodology. The results of the study indicated a cyclical feedback between the trade balance and the real exchange rate depreciation of the Naira. However, the analysis finds no empirical evidence in favour of the short-run deterioration of the trade balance as implied by the J-curve hypothesis. Rather, what is empirically supported is the cyclical trade effect of exchange rate shocks. As it were, a real exchange rate shock will initially improve then worsen and then improve the country's aggregate trade balance. The instant improvement in the trade balance which is correlated with real depreciation provides no support for the J-curve hypothesis in the Nigerian trade balance. Hence, the short-run predictions of the $\mathrm{J}$-curve are not observable in Nigeria. Ademola, Olusuyi, Ibiyemi and Babatunde (2013) empirically examined the impact of trade openness on economic growth in Nigeria. The study employed ordinary least square regression to find out the relationship between trade openness and economic growth. The result suggest that the positive sign of the coefficient of non oil export, trade openness underscore their increasing relationship with gross domestic product, increasing in their value link to increase in GDP all other things being equal. The negative sign of the exchange rate and balance of payment show that a depreciating exchange rate and unfavourable bank payment lead to a decline in gross domestic product. The joint significance of all coefficient estimate was evaluated using $\mathrm{F}$ test and the outcome of the evaluation indicate that the coefficient is statistically insignificant which means that GDP is a poor estimate. Ijeoma (2013) examined the impact and policy strategies of trade liberalization in Nigeria. The objective of this study was to determine the level of implementation of trade instruments and strategies, and to ascertain if the policy direction for foreign trade has been vigorously pursued over the years in
Nigeria. On a cross section of importers and exporters, top banks management staff and members of the legislative house in Nigeria. The statistical tool used in analyzing the data was the Chi-square test statistic. From the result of the analysis, it was found that majority of the respondents believed that the implementation of trade instrument and strategies has been very low since the option "very low" recorded the highest column total. In the final analysis, studies on trade liberalization and trade flows in Nigeria are rife. Scholars have investigated the subject from various standpoints and with varying literary perspectives. However, the empirical studies reviewed show that most scholars agreed that trade liberalization impact positively on economic growth of any country while some did not agree with the findings that trade liberalization impact positively rather they came up that it impact negatively on the economy. In addition, most of the studies reviewed failed to address the impact of trade liberalization policies and trade flows on economic growth and these trade liberalization policies may include any policy that directly affects the flow of goods and services between countries, including import tariffs, import quotas, voluntary export restraints, export taxes, export subsidies, and so on. Available literature reviewed in this study did not attempt or adopt the trade policies like import tariffs, import quotas, voluntary export restraints, export taxes and export subsidies in its analysis. This study fills the literature and knowledge gap by modeling the import tariffs, import quotas, voluntary export restraints, export taxes, export subsidies among other variables.

\section{Theoretical Framework}

There are a number of theories on trade flows and how they engender economic prosperity of nations. Some of the theories include: Mercantilist Trade Theory, Absolute Advantage Trade Theory, Comparative Advantage Theory, Hecksher - Ohlin Trade Theory: Harrod-Domar Growth Model, Traditional Neoclassical Growth Theory, Endogenous Growth Theory, Classical Theory of Trade, The Theory of Factor Proportion, The Product Life Cycle Theory, systems theory, surplus theory, new trade theories, surplus labour theory among others (Nageri et al, 2013; Afolabi, Danladi \& Azeez, 2017; Adeleye, Adeteye \& Adewuyi, 2015). However, this study will be anchored on the Systems Theory because of its suitability in explaining the subject of trade liberalization and trade flows in this study. According to Monisola (2014), the history of systems theories 
includes contributions from such seminar thinkers as Alfred North Whitehead, Ludwig von Bertalanffy, Anatol Rapoport, Kenneth Boulding, Paul A. Weiss, Ralph Gerard, Kurt Lewin, Roy R. Grinker, William Gray, Nicolas Rizzo, Karl Menninger, Silvano Arieti(Laszlo and Kriooner, 2013). The theory assumes that there is an interaction and interrelationship between and among countries for their continued survival. The relationship comes in form of all the human interaction networks, small and large, from the household to the global trade, cultural, economic and political institutions and connection among them (Adeleye, Adeteye \& Adewuyi, 2015; Dun, 2012)

In applying the systems theory to this study, available literature asserts that trade liberalization is a powerful means by which the rest of the world's economics are been firmly integrated into global capitalist economy (Adeleye, Adeteye \& Adewuyi, 2015; Ogunleye, 2003). According to Adeleye, Adeteye \& Adewuyi, 2015), the system theory rest on belief that there is international division of labour, which divides the world into core countries, semi-periphery countries and the periphery countries. Core countries focus on higher skill, capital intensive production, and the rest of the world focuses on low-skill, labour-intensive production and extraction of raw materials. This constantly reinforces the dominance of the core countries. Nonetheless, the system is dynamic and individual states can gain or lose the core status over time (Wikipedia encyclopedia, 2012). In reality, many international relations are competitive rather than cooperative and antagonistic. In this terminology, the core is the developed industrialized part of the world, and the periphery is the "underdeveloped". The periphery is typically raw materials-exporting oriented and of cause poor part of the world. The market interaction is the means by which the core exploits the periphery (Wikipedia encyclopedia, 2012; Adeleye, Adeteye \& Adewuyi, 2015). This demonstrates the challenges faced by the emerging economies typically Nigeriain terms of trade liberalization.

\section{METHODOLOGY}

Based on a modified endogenous growth function, this study employs a multiple regression technique to estimate the impact of trade liberalization on Nigerian economic growth.
The model for this study will be based on the insight gain from empirical literature reviewed in this study. This modification was the introduction of some of trade policies in the model. These trade policies include import tariffs, import quotas, export taxes and export subsidies. Thus, economic growth which will be the dependent variable will be proxied by real gross domestic product growth rate (RGDP) while the explanatory variables include trade flow as to be proxied by trade openness and trade liberalization as import tariffs, import quotas, export taxes and export subsidies. Therefore, the model for this study is stated as followed:

The structural form of the model is:

$\mathrm{GDP}=\mathrm{f}(\mathrm{TRAL}, \mathrm{TARF}, \mathrm{QUO}, \mathrm{TAXE}, \mathrm{SUB})$

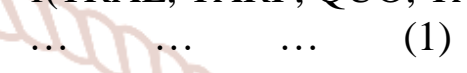

The mathematical form of the model is:

$\mathrm{GDP}=\beta_{0}+\beta_{1} \mathrm{TRAL}+\beta_{2} \mathrm{TARF}+\beta_{3} \mathrm{QUO}+\beta_{4} \mathrm{TAXE}$ $+\beta_{5}$ SUB

The econometric form of the model is:

$\mathrm{GDP}=\beta_{0}+\beta_{1} \mathrm{TRAL}+\beta_{2} \mathrm{TARF}+\beta_{3} \mathrm{QUO}+\beta_{4} \mathrm{TAXE}$ $+\beta_{5} \mathrm{SUB}+\mu_{\mathrm{i}}$

Where;

GDP = Gross Domestic Product proxied by GDP growth rate

TRAL $=$ Trade flows proxied by trade openness

TARF $=$ Import tariffs

QUO $=$ Import quotas

$\mathrm{TAXE}=$ Export taxes

SUB $=$ Export subsidies

$\mathrm{f}=$ Functional relationship

$\beta_{0}=$ intercept of the model

$\beta_{1}-\beta_{5}=$ parameters of the regression coefficients

$\mu_{i}=$ Stochastic error term

\section{Explanation of variables}

A. Gross Domestic Product (GDP): GDP is commonly used as an indicator of the economic health of a country, as well as to gauge a country's standard of living. GDP is also the total value of the goods and services produced by the people of a nation during a year not including the value of income earned in foreign countries. In this study GDP will be proxied by GDP growth rate.

B. Trade flows (TRAL): TRAL is the removal or reduction of restrictions or barriers on the free exchange of goods between nations. This includes the removal or reduction of both tariff (duties and surcharges) and non-tariff obstacles (like licensing 
rules, quotas and other requirements). The easing or eradication of these restrictions is often referred to as promoting "free trade." Trade liberalization will be proxied by trade openness.

C. Import Tariffs (TARF): An import tariff is a tax placed by governments on commodities that are shipped into a country from a foreign country. These taxes are often a way to discourage a country's consumers from buying products from another country and to support domestic products and services. Governments generally have the right to determine what products will have a tariff and how much that tax will be. Tariffs are used to restrict trade, as they increase the price of imported goods and services, making them more expensive to consumers. They are one of several tools available to shape trade policy. TARF will be proxied by prices of imported goods.

D. Import Quotas (QUO): An import quota is a limit on the quantity of a good that can be produced abroad and sold domestically. It is a type of protectionist trade restriction that sets a physical limit on the quantity of a good that can be imported into a country in a given period of time. It is also a governmental restriction on the quantities of a particular commodity that may be imported within a specific period of time, usually with the goal of protecting domestic producers of that commodity from foreign competition. Import quotas are foreign trade policies undertaken by domestic governments that are intended to "protect" domestic production by restricting foreign competition. In general, a quota is simply a quantity restriction placed on a good, service, or activity. QUO will be proxied by import fees.

E. Export taxes (TAXE): Taxes on exports are all levies on goods being transported out of the country or services being delivered to nonresidents by residents. Rebates on exported goods that are repayments of previously paid general consumption taxes, excise taxes, or import duties are deducted from the gross amounts receivable from these taxes, not from amounts receivable from export taxes. Tax exporting occurs when a country (or other jurisdiction) shifts its tax burden (partially) abroad. Tax exporting does not necessarily involve direct taxation of foreign residents. It can also work through other economic channels, such as price changes. Export taxes were measured by levies on goods being transported out of the country or services being delivered to nonresidents by residents
F. Export subsidies (SUB): Export subsidy is a government policy to encourage export of goods and discourage sale of goods on the domestic market through direct payments, low-cost loans, tax relief for exporters, or government-financed international advertising. An export subsidy reduces the price paid by foreign importers, which means domestic consumers pay more than foreign consumers. Governments also regulate trade by providing various kinds of support for export producers. Export subsidies come in a variety of forms, but they share the trait in benefitting from government funds. These funds enable them to offer their products or services to other countries at lower prices. The objective of this support is to enable domestic producers to "win" sales by undercutting the prices charged by producers in foreign countries. In this study, export subsidy was proxied by export expansion grant.

\section{Method of data analysis}

The economic technique employed in the study is the ordinary least square (OLS). This is because the OLS computational procedure is fairly simple a best linear estimator among all unbiased estimation, efficient and shown to have the smallest (minimum variance) thus, it become the best linear unbiased estimator (BLUE) in the classical linear regression (CLR) model. Basic assumptions of the OLS are related to the forms of the relationship among the distribution of the random variance $\left(\mu_{\mathrm{i}}\right)$.

OLS is a very popular method and in fact, one of the most powerful methods of regression analysis. It is used exclusively to estimate the unknown parameters of a linear regression model. The Economic views (Eviews) software will be adopted for regression analysis.

\section{Stationarity (unit root) test:}

The importance of this test cannot be overemphasized since the data to be used in the estimation are timeseries data. In order not to run a spurious regression, it is worthwhile to carry out a stationary test to make sure that all the variables are mean reverting that is, they have constant mean, constant variance and constant covariance. In other words, that they are stationary. The Augmented Dickey-Fuller (ADF) test would be used for this analysis since it adjusts for serial correlation. 
Decision rule: If the ADF test statistic is greater than the MacKinnon critical value at 5\% (all in absolute term), the variable is said to be stationary. Otherwise it is non stationary.

\section{Cointegration test:}

Econometrically speaking, two variables will be cointegrated if they have a long-term, or equilibrium relationship between them. Cointegration can be thought of as a pre-test to avoid spurious regressions situations (Granger, 1986). As recommended by Gujarati (2004), the ADF test statistic will be employed on the residual.
Decision Rule: if the ADF test statistic is greater than the critical value at 5\%, then the variables are cointegrated (values are checked in absolute term)

\section{PRESENTATION OF EMPIRICAL RESULT Summary of Stationary Unit Root Test}

Establishing stationarity is essential because if there is no stationarity, the processing of the data may produce biased result. The consequences are unreliable interpretation and conclusions. We test for stationarity using Augmented Dickey-Fuller (ADF) tests on the data. The ADF tests are done on level series, first and second order differenced series. The result of regression is presented in table 1 below.

Table 1: Summary of ADF test results

\begin{tabular}{|c|c|c|c|c|c|c|}
\hline Variables & $\begin{array}{c}\text { ADF } \\
\text { Statistics }\end{array}$ & $\begin{array}{l}\text { Lagged } \\
\text { Difference }\end{array}$ & $\begin{array}{l}1 \% \text { Critical } \\
\text { Value }\end{array}$ & $\begin{array}{l}5 \% \text { Critical } \\
\text { Value }\end{array}$ & $\begin{array}{l}10 \% \text { Critical } \\
\text { Value }\end{array}$ & $\begin{array}{l}\text { Order of } \\
\text { Integration }\end{array}$ \\
\hline GDP & -5.896859 & 1 & -3.653730 & -2.957110 & -2.617434 & $I(1)$ \\
\hline TRAL & -6.659575 & 1 & -3.653730 & -2.957110 & -2.617434 & $I(1)$ \\
\hline TARF & -7.309947 & 1 & -3.653730 & -2.957110 & -2.617434 & $I(1)$ \\
\hline QUO & -4.791580 & 1 & -3.653730 & -2.957110 & -2.617434 & $I(1)$ \\
\hline TAXE & -8.050680 & 1 & -3.653730 & -2.957110 & -2.617434 & $I(1)$ \\
\hline SUB & -5.656894 & 1 & -3.653730 & -2.957110 & -2.617434 & $I(1)$ \\
\hline
\end{tabular}

Source: Researchers computation

Evidence from unit root table above shows that none of the variables are stationary at level difference, that is, $I(0)$. All the variables are stationary at their first difference, that is $I(1)$. Since the ADF absolute value of each of these variables is greater than the 5\% critical value, they are all stationary at their different integrated differences. They are also significant at $1 \%$ and $10 \%$ respectively. Since one of the variables is integrated at level form and some at first difference, we go further to carry out the cointegration test. The essence is to show that although all the variables are stationary, whether the variables have a long term relationship or equilibrium among them. That is, the variables are cointegrated and will not produce a spurious regression.

\section{Summary of Cointegration Test}

Cointegration means that there is a correlations hip among the variables. Cointegration test is done on the residual of the model. Since the unit root test shows that none of the variable is stationary at level $I(0)$ rather all the variables are at first difference 1(1), we therefore test for cointegration among these variables. The result is presented in tables 4.2 below for Trace and Maximum Eigenvalue co integration rank test respectively.

Table 2: Summary of Johansen Cointegration Test

\begin{tabular}{|c|c|c|c|c|}
\hline \multicolumn{5}{|c|}{ Unrestricted Cointegration Rank Test (Trace) } \\
\hline $\begin{array}{c}\text { Hypothesized } \\
\text { No. of CE(s) }\end{array}$ & Eigen value & $\begin{array}{c}\text { Trace } \\
\text { Statistic }\end{array}$ & $\begin{array}{c}\mathbf{0 . 0 5} \\
\text { Critical Value }\end{array}$ & Prob.*** \\
\hline None $*$ & 0.863871 & 149.5939 & 95.75366 & 0.0000 \\
\hline At most 1 * & 0.776203 & 83.78693 & 69.81889 & 0.0026 \\
\hline At most 2 $*$ & 0.405348 & 50.38536 & 47.85613 & 0.0009 \\
\hline At most 3 $*$ & 0.265071 & 37.23267 & 29.79707 & 0.0028 \\
\hline At most 4 & 0.137541 & 7.069284 & 15.49471 & 0.5696 \\
\hline At most 5 & 0.064106 & 2.186345 & 3.841466 & 0.1392 \\
\hline
\end{tabular}


International Journal of Trend in Scientific Research and Development (IJTSRD) ISSN: 2456-6470

\begin{tabular}{|c|c|c|c|c|}
\hline \multicolumn{5}{|c|}{ Unrestricted Cointegration Rank Test (Maximum Eigenvalue) } \\
\hline $\begin{array}{c}\text { Hypothesized } \\
\text { No. of CE(s) }\end{array}$ & Eigen value & $\begin{array}{c}\text { Max-Eigen } \\
\text { Statistic }\end{array}$ & $\begin{array}{c}0.05 \\
\text { Critical Value }\end{array}$ & Prob.*** \\
\hline None * & 0.863871 & 65.80695 & 40.07757 & 0.0000 \\
\hline At most 1 * & 0.776203 & 49.40158 & 33.87687 & 0.0004 \\
\hline At most 2 & 0.405348 & 17.15269 & 27.58434 & 0.5669 \\
\hline At most 3 & 0.265071 & 10.16338 & 21.13162 & 0.7292 \\
\hline At most 4 & 0.137541 & 4.882939 & 14.26460 & 0.7566 \\
\hline At most 5 & 0.064106 & 2.186345 & 3.841466 & 0.1392 \\
\hline \multicolumn{7}{|c|}{ Source: Researchers computation } \\
\end{tabular}

Table 2 indicates that trace have only 4 cointegrating variables in the model while Maximum Eigenvalue indicated only 2 cointegrating variables. Both the trace statistics and Eigen value statistics reveal that there is a long run relationship between the variables. That is, the linear combination of these variables cancels out the stochastic trend in the series. This will prevent the generation of spurious regression results. Hence, the implication of this result is a long run relationship between economic growth and other variables used in the model.

\section{Presentation of result}

The result of the regression test is presented in table 3 below.

Dependent Variable: GDP

Method: Least Squares

Sample: 19802017

Included observations: 38

Table 3: Summary of regression results

\begin{tabular}{|c|c|c|c|c|}
\hline Variable & Coefficient & Std. Error & t-Statistic & Prob. \\
\hline C & 13.65292 & 1.586529 & 8.605529 & 0.0000 \\
\hline TRAL & 3.103851 & 0.001931 & 5.993892 & 0.0001 \\
\hline TARF & -0.016923 & 0.048691 & -3.195943 & 0.0005 \\
\hline QUO & -0.102660 & 0.002789 & -4.539390 & 0.0002 \\
\hline TAXE & -0.303048 & 0.041463 & -4.797047 & 0.0003 \\
\hline SUB & 0.302470 & 0.006804 & 1.363060 & 0.0200 \\
\hline R-squared & 0.737018 & \multicolumn{2}{|c|}{ F-statistic } & 12.33118 \\
\hline Adjusted R-squared & 0.677249 & Prob(F-statistic) & 0.000009 \\
\hline S.E. of regression & 1.473944 & Durbin-Watson stat & 1.893361 \\
\hline
\end{tabular}

Source: Researchers computation

\section{Evaluation of estimates}

To discuss the regression results as presented in table 3, we employ economic a priori criteria, statistical criteria and econometric criteria.

\section{Evaluation based on economic a priori criteria}

This subsection is concerned with evaluating the regression results based on a priori (i.e., theoretical) expectations. The sign and magnitude of each variable coefficient is evaluated against theoretical expectations.

From table 3, it is observed that the regression line have a positive intercept as presented by the constant $(\mathrm{c})=$ 13.65292. This means that if all the variables are held constant or fixed (zero), GDP will be valued at 13.65292. Thus, the a-priori expectation is that the intercept could be positive or negative, so it conforms to the theoretical expectation. 
It is observed in table 3 that trade flows and export subsidies have a positive impact on economic growth in Nigeria, while import tariffs, impact quotas and export taxes have a negative impact on economic growth in Nigeria.

From the regression analysis, it is observed that all the variables conform to the a priori expectation of the study. Thus, table 4 summarises the a priori test of this study.

Table 4: Summary of economic a priori test

\begin{tabular}{|c|c|c|c|c|c|}
\hline \multirow{2}{*}{ Parameters } & \multicolumn{2}{|c|}{ Variables } & \multirow{2}{*}{ Expected Relationships } & \multirow{2}{*}{ Observed Relationships } & \multirow{2}{*}{ Conclusion } \\
\hline & Regressand & Regressor & & & \\
\hline$\beta_{0}$ & GDP & Intercept & $+/-$ & + & Conform \\
\hline$\beta_{1}$ & GDP & TRAL & + & + & Conform \\
\hline$\beta_{2}$ & GDP & TARF & - & - & Conform \\
\hline$\beta_{3}$ & GDP & QUO & - & - & Conform \\
\hline$\beta_{4}$ & GDP & TAXE & - & - & Conform \\
\hline$\beta_{5}$ & GDP & SUB & 3 & he & Conform \\
\hline
\end{tabular}

Source: Researchers compilation

\section{Evaluation based on statistical criteria}

This subsection applies the $\mathrm{R}^{2}$, adjusted $\mathrm{R}^{2}$, the S.E and the $\mathrm{f}$-test to determine the statistical reliability of the estimated parameters. These tests are performed as follows:

From our regression result, the coefficient of determination $\left(\mathbf{R}^{\mathbf{2}}\right)$ is given as 0.737018 , which shows that the explanatory power of the variables is moderately high and/or strong. This implies that $74 \%$ of the variations in the growth of the trade flows, import tariffs, import quotas, export taxes and export subsidies are being accounted for or explained by the variations in economic growth in Nigeria. While other determinants of economic growth not captured in the model explain just $26 \%$ of the variation in economic growth in Nigeria.

The adjusted $\mathbf{R}^{2}$ supports the claim of the $\mathrm{R}^{2}$ with a value of 0.677249 indicating that $68 \%$ of the total variation in the dependent variable (economic growth is explained by the independent variables (the regressors)). Thus, this supports the statement that the explanatory power of the variables is moderately high and strong.

The F-statistic: The F-test is applied to check the overall significance of the model. The F-statistic is instrumental in verifying the overall significance of an estimated model. The hypothesis tested is:

$\mathrm{H}_{0}$ : The model has no goodness of fit

$\mathrm{H}_{1}$ : The model has a goodness of fit

Decision rule: Reject $\mathrm{H}_{0}$ if $\mathrm{F}_{\mathrm{cal}}>\mathrm{F}_{\alpha}(\mathrm{k}-1, \mathrm{n}-\mathrm{k})$ at $\alpha=5 \%$, accept if otherwise.

Where

$\mathrm{V}_{1} / \mathrm{V}_{2}$ Degree of freedom (d.f)

$\mathrm{V}_{1}=\mathrm{n}-\mathrm{k}, \mathrm{V}_{2}=\mathrm{k}-1$ :

Where; $\mathrm{n}$ (number of observation); $\mathrm{k}$ (number of parameters)

Where $\mathrm{k}-1=6-1=5$

Thus, $\mathrm{n}-\mathrm{k}=35-6 \quad=29$

Therefore, $\mathrm{F}_{0.05(5,29)}=2.21 \quad$ (From the $\mathrm{F}$ table) $\quad \ldots$ F-table

F-statistic $=12.33118 \quad$ (From regression result) $\quad \ldots$ F-calculated

Since the F-calculated > F-table, we reject $\mathrm{H}_{0}$ and accept $\mathrm{H}_{1}$ that the model has goodness of fit and is statistically different from zero. In other words, there is significant impact between the dependent and independent variables in the model. 


\section{Evaluation based on econometric criteria}

In this subsection, the following econometric tests are used to evaluate the result obtained from our model: autocorrelation, heteroscedasticity and multicolinearity.

\section{Test for Autocorrelation}

Using Durbin-Watson (DW) statistics which we obtain from our regression result in table 3, it is observed that DW statistic is 1.893361 or approximately 2 . This implies that there is no autocorrelation since $\mathrm{d}^{*}$ is approximately equal to two. 1.893361 tends towards two more than it tends towards zero. Therefore, the variables in the model are not autocorrelated and that the model is reliable for predications.

\section{Test for Heteroscedasticity}

This test is conducted using the white's general heteroscedascity test. The hypothesis testing is thus:

$\mathrm{H}_{0}$ : There is a heteroscedasticity in the residuals

$\mathrm{H}_{1}$ : There is no heteroscedasticity in the residuals

Decision rule: Reject $\mathrm{H}_{0}$ if the computed $\mathrm{f}$-statistics is significant. Otherwise, accept at 5\%level of significance. Since the F-calculated > F-table, computed f-statistics is significant. Hence, since the F-calculated is significant, we reject $\mathrm{H}_{0}$ and accept $\mathrm{H}_{1}$ that the model has no heteroscedasticity in the residuals and therefore, reliable for predication.

\section{Test for Multicolinearity}

This means the existence of an exact linear relationship among the explanatory variable of a regression model. This means the existence of an exact linear relationship among the explanatory variable of a regression model. This will be used to check if collinearity exists among the explanatory variables. The basis for this test is the correlation matrix obtained using the series. The result is presented in table 5 below.

Table 5: Summary of Multicollinearity test

\begin{tabular}{|c|c|c|}
\hline Variables & Correlation Coefficients & Conclusion \\
\hline TRAL and TARF & 0.409527 & No multicollinearity \\
\hline TRAL and QUO & 0.150126 & No multicollinearity \\
\hline TRAL and TAXE & 0.639668 & No multicollinearity \\
\hline TRAL and SUB & 0.149280 & No multicollinearity \\
\hline TARF and QUO & 0.451401 & No multicollinearity \\
\hline TARF and TAXE & 0.721823 & No multicollinearity \\
\hline TARF and SUB & -0.065427 & No multicollinearity \\
\hline QUO and TAXE & 0.516913 & No multicollinearity \\
\hline QUO and SUB & -0.009027 & No multicollinearity \\
\hline TAXE and SUB & 0.103633 & No multicollinearity \\
\hline
\end{tabular}

Source: Researchers computation

Decision Rule: From the rule of Thumb, if correlation coefficient is greater than 0.8 , we conclude that there is multicolinearity but if the coefficient is less than 0.8 there is no multicolinearity. We therefore, conclude that the explanatory variables are not perfectly linearly correlated.

\section{Test of research hypotheses}

The t-test is used to know the statistical significance of the individual parameters. Two-tailed tests at 5\% significance level are conducted. The Result is shown on table 4.6 below. Here, we compare the estimated or calculated $\mathrm{t}$-statistic with the tabulated $\mathrm{t}$-statistic at $\mathrm{t}_{\alpha / 2}=\mathrm{t}_{0.05}=\mathrm{t}_{0.025}$ (two-tailed test).

Degree of freedom $(\mathrm{df})=\mathrm{n}-\mathrm{k}=35-6=29$

So, we have: $\mathrm{T}_{0.025(29)} \quad=2.045 \quad \ldots \quad$ Tabulated $\mathrm{t}$-statistic 
In testing the working hypotheses, which partly satisfies the objectives of this study, we employ a 0.05 level of significance. In so doing, we are to reject the null hypothesis if the t-value is significant at the chosen level of significance; otherwise, the null hypothesis will be accepted. This is summarized in table 6 below.

Table 6: Summary of t-statistic

\begin{tabular}{|c|c|c|c|}
\hline Variable & t-tabulated $\left(\mathrm{t}_{\mathrm{\alpha} / \mathbf{2})}\right)$ & $\mathrm{t}$-calculated $\left(\mathrm{t}_{\mathrm{cal}}\right)$ & Conclusion \\
\hline Constant & \pm 2.045 & 8.605529 & Statistically Significance \\
\hline TRAL & \pm 2.045 & 5.993892 & Statistically Significance \\
\hline TARF & \pm 2.045 & -3.195943 & Statistically Significance \\
\hline QUO & \pm 2.045 & -4.539390 & Statistically Significance \\
\hline TAXE & \pm 2.045 & -4.797047 & Statistically Significance \\
\hline SUB & \pm 2.045 & 1.363060 & Statistically Insignificance \\
\hline
\end{tabular}

Source: Researchers computation

We begin by bringing our working hypothesis to focus in considering the individual hypothesis. From table 6, the t-test result is interpreted below;

For TRAL, $t_{\alpha / 2}<t_{c a l}$, therefore we reject the null hypothesis and accept the alternative hypothesis. This means that TRAL have a significant impact on GDP.

For TARF, $t_{\alpha / 2}<t_{c a l}$, therefore we reject the null hypothesis and accept the alternative hypothesis. Thus, TARF do have a significant impact on GDP.

For QUO, $t_{\alpha / 2}<t_{c a l}$, therefore we accept the null hypothesis and reject the alternative hypothesis. This means that QUO do has a significant effect on GDP.

For TAXE, $t_{\alpha / 2}<t_{c a l}$, therefore we accept the null hypothesis and reject the alternative hypothesis. This means that TAXE do has a significant effect on GDP.

For SUB, $t_{\alpha / 2}>t_{c a l}$, therefore we accept the null hypothesis and reject the alternative hypothesis. Thus, SUB has no significant impact on GDP.

From the analysis so far, it can be observed that trade flows have contributed positively to the economic growth in Nigeria. The study has shown that the degree of trade openness of the Nigerian economy to other countries' economy has not only contributed much to the growth of the economy but also has better the welfare and improved the standard of living of the citizens in the country. The study concluded that positive significant impact of the trade flows on economic growth in Nigeria is as a result of the removal or reduction of restrictions or barriers on the free exchange of goods between nations. This includes the removal or reduction of both tariff (duties and surcharges) and non-tariff obstacles (like licensing rules, quotas and other requirements) in Nigeria. The study shows that import tariff and quotas measured by prices of imported goods and import fees respectively have portrayed a negative significance relationship in the Nigerian economy respectively. This is as a result of high import tariffs and low import quotas that the Nigerian governments do adapt. The Nigerian government has put in place one or two events or actions to reduce the prices of imported goods thereby encouraging the local industries and also, quotas which is a limit on the quantity of a good that can be produced abroad and sold domestically. Governments undertakes import quotas as a foreign trade policy which intended to "protect" domestic production by restricting foreign competition. Governments generally have the right to determine what products will have a tariff and how much that tax will be, therefore, contributing to the economic growth and development in Nigeria. Export taxes and subsidy are also trade liberalization policies that Nigerian government has adapted in the recent years. Currently, both export taxes and subsidy has contributed immensely to the growth and development of the Nigerian economy as a result of high export taxes and subsidies. The study has shown that export taxes have a negative significant relationship in Nigerian economy while export subsidy is positively insignificant impact in Nigerian economy. The Nigerian government has succeeded in offering their products or services to other countries at lower prices which have contributed to the growth of the economy while in terms of export taxes, the Nigerian government has tried to raise the levies on goods being exported out of the country or services 
being delivered to non-residents by residents in order to add value to the economy.

\section{Summary of findings}

The study attempted to explain the impact of trade liberalization and trade flows on Nigerian economic growth from 1980 -2017 using Ordinary least Square (OLS) technique method. All data used are secondary data obtained from the Statistical Bulletin of Central Bank of Nigeria (CBN).

In executing the study, the OLS techniques was applied after determining stationarity of our variables using the ADF Statistic, as well as the cointegration of variables using the Johansen approach and was discovered that the variables are stationary and have a long term relationship among the variables in the model.

From the result of the OLS, it is observed that trade flows and export subsidies have a positive relationship with economic growth. This means that when trade flows and export subsidies are increasing, it will bring about more growth in Nigerian economy. On the other hand, import tariffs, import quotas and export taxes have a negative impact on economic growth in Nigeria. This means that if import tariffs, import quotas and export taxes are falling, there will be increase in economic growth.

From the regression analysis, the result show that all the variables conform to the a priori expectation of the study, where economic growth have a positive impact on trade flows and export subsidies and a negative impact with import tariffs, import quotas and export taxes.

From the empirical reviewed work, some authors argued that trade liberalization and trade flows is positively related to economic growth; while some authors argued that it is negatively related. However, from empirical analysis of this study, it was found that trade liberalization and trade flows are positively related to economic growth in Nigeria.

The F-test conducted in the study shows that the model has a goodness of fit and is statistically different from zero. In other words, there is a significant impact between the dependent and independent variables in the model.
The findings of the study also show that trade flows, import tariffs, import quotas and export taxes are statistically significant in explaining the Nigerian economy while export subsidy is statistically insignificant.

Finally, the study shows that there is a long run relationship exists among the variables. Both $\mathrm{R}^{2}$ and adjusted $\mathrm{R}^{2}$ show that the explanatory power of the variables is very high or strong. The standard errors show that all the explanatory variables were all low. The low values of the standard errors in the result show that some level of confidence can be placed on the estimates.

\section{Recommendations}

This paper principal focus was to unravel the impact of trade liberalization on the Nigerian economy from 1980 to 2017 . To achieve these goals, details analysis of the effects of trade flows, impact tariffs, impact quotas, export taxes and export subsidy on the economy was carried out. The result indicates that there is a very strong positive impact of all the variables and each variable based on the analysis and discussion of results above have a significant effect on economic growth in Nigeria except export subsidy but it conforms to the study a priori expectation.

Government should encourage import liberalization through reduction in tariff rates, gradual removal of Non-Tariff Barriers (NTB), outright banning of certain goods which will ensure that our imports, following trade liberalization, is directed mainly on intermediate and capital goods. Imports of consumables would be brought to nil and therefore there would be a corresponding increase in the production of competitive import. Consequently, a higher component of intermediate and capital goods in total import will bring about an improvement in the production of tradable goods, which in turn can provoke increase in exports. This by implication would increase the level of export in the country thereby leading to economic growth in the country.

The Nigerian government should liberalized trade policy in such a way that will bring about import substitution and export promotion via import quotas and tariffs and export taxes and subsidy respectively.

Since import tariffs and quotas are significant in explaining in Nigerian economy, the government is hereby advised encouraged local industries by 
adapting high import tariffs and low import quotas. This will discourage high dependent on importation goods and encourage our local industries to grow.

Finally, the government should vigorously seek to improve the international stand of the economy with other economies of the world so as to enlarge the market for Nigerian exports. It should also re-orient its policy towards the external sector and ensure that the sector contribute optimally to output growth.

\section{REFERENCES}

1. Adeleye J. O., Adeteye O. S. \& Adewuyi M. O. (2015). Impact of International Trade on Economic Growth in Nigeria (1988-2012). International Journal of Financial Research, 6(3), 163-172.

2. Ademola, I. S., Olusuyi, A. E. \& Ibiyemi, O. \& Babatunde, G. A. (2013). Trade openess and Economic Growth in Nigeria $(1981-2009)$ An Empirical Analysis. International Journal of Humanities and Social Science Invention, 2(6), 101-113.

3. Afolabi, B., Danladi, J. D. \& Azeez, M. I. (2017). International Trade and Economic Growth in Nigeria. Global Journal of Human-Social Science: Economics, 17(5), 29-39.

4. Akinyemi, K., Ebiefie, V., Tinuola., Adekojo, T. A. \& Ibiyemi, I. A. (2014). Trade Liberalization and Employment Generation in Nigeria. International Journal of Innovation and Scientific Research, 10(1), 118-124.

5. Azeez, B A ., Dada, S O \& Aluko, O A. (2014). Effect of international trade on Nigerian economic growth: THE $21^{\text {ST }}$ Century Experience. International Journal of Economics, Commerce and Management. 2(10), 1-8.

6. Dun, C. (2012), "Dependency and World System'.http://www.sociologyencylopedia.com/fr ag mage/media/dependency.

7. Echekoba, F. N., Okonkwo V. I. \& Adigwe P. K (2015). Trade liberalization and economic growth: The nigerian experience (1971-2012). Journal of Poverty, Investment and Development, 14: 51-72.

8. Ejike, D. C., Anah, S. A. \& Onwuchekwa, F. C. (2018). Trade Liberalization And Economic Growth In Nigeria: A Cointegration Analysis (1980-2015). IJRDO - Journal of Business Management, 4(5), 81-94.
9. Eleanya, K. N. (2013). Openness and Economic Growth in Nigeria. Journal of Education and Practice, 4(1), 68-73.

10. Ijeoma, N. B. (2013). Trade Liberalization in Nigeria: An Examination of Impact and Policy Strategies. International Journal of Scientific \& Engineering Research, 4(12), 1277-1283.

11. Laszlow, L \& Krippner, S. (1998), “Systems Theories: Their Origins, Foundations, and Development' 'http://archive.syntonyquest.org/e/c /ree/ResourcePDFs/system Theory.pdf

12. Monisola, O. J. (2014). Public Policy and Trade Liberalisation in Nigerian Economic Development. Research on Humanities and Social Sciences, 4(15), 91-96.

13. Nageri, K. I., Ajayi, O., Olodo, H. B. \& Abina, B. M. (2013). An empirical study of growth through trade: Nigeria evidence. Arabian Journal of Business and Management Review (OMAN Chapter), 3(5), 1-12.

14. Nwinee, B. F. \& Olulu-Briggs, O. V. (2016). Trade Openness, Financial Development, and the Nigerian Economy. American International Journal of Contemporary Research, 6(3), 170183.

15. Ogunleye, J. M. (2003), "Globalisation and Economic Self-reliance; A case study of Nigeria', M.Sc. Thesis, Department of Political Science, University of Ado-Ekiti, Ado-Ekiti.

16. Ojeyinka, T. A. \& Adegboye, A. A. (2017). Trade Liberalization and Economic Performance in Nigeria: Evidence from Agricultural and Manufacturing sectors. African Journal of Economic Review, 5(3), 1-14.

17. Olaifa, F. G., Subair, K. \& Biala, M.I.(2015). Trade liberalization and economic growth In Nigeria; A cointegration analysis. Journal of Business, Economics \& Finance, 2(3), 43-52.

18. Soi, N. (2013). Effect of International Trade on Economic Growth In Kenya. European Journal of Business and Management, 5(10), 131-137.

19. Ude, D. K. \& Agodi, J. E. (2015). Does Trade Openness Make Sense? Investigation of Nigeria Trade Policy. International Journal of Academic Research in Economics and Management Sciences, 4(1), 6-21. 
20. Umoru, D. (2013). Employment and International Trade Flows In Nigeria: VECM ANALYSIS. International Affairs and Global Strategy, 8: 1-19.

21. Umoru, D. (2013). Trade Liberalization and Industrial Growth in Nigeria. Journal of Poverty, Investment and Development, 1: 148-156.

22. Umoru, D. \& Oseme, A. S. (2013). Trade flows and exchange rate shocks in Nigeria: An empirical result. Asian Economic and Financial Review, 3(7):948-977.
23. Wikipedia Encyclopedia; System Theory, Wikipedia, the free encyclopedia. En.wikipedia.org/wiki/world-system theory.

24. Winters, A. (2002). Trade Policies for Poverty Alleviation. In Hoekman, Bernard, Mattoo, Aaditya and English, Philip (eds). Development, Trade and the WTO, A Handbook. World Bank, Washington D.C.

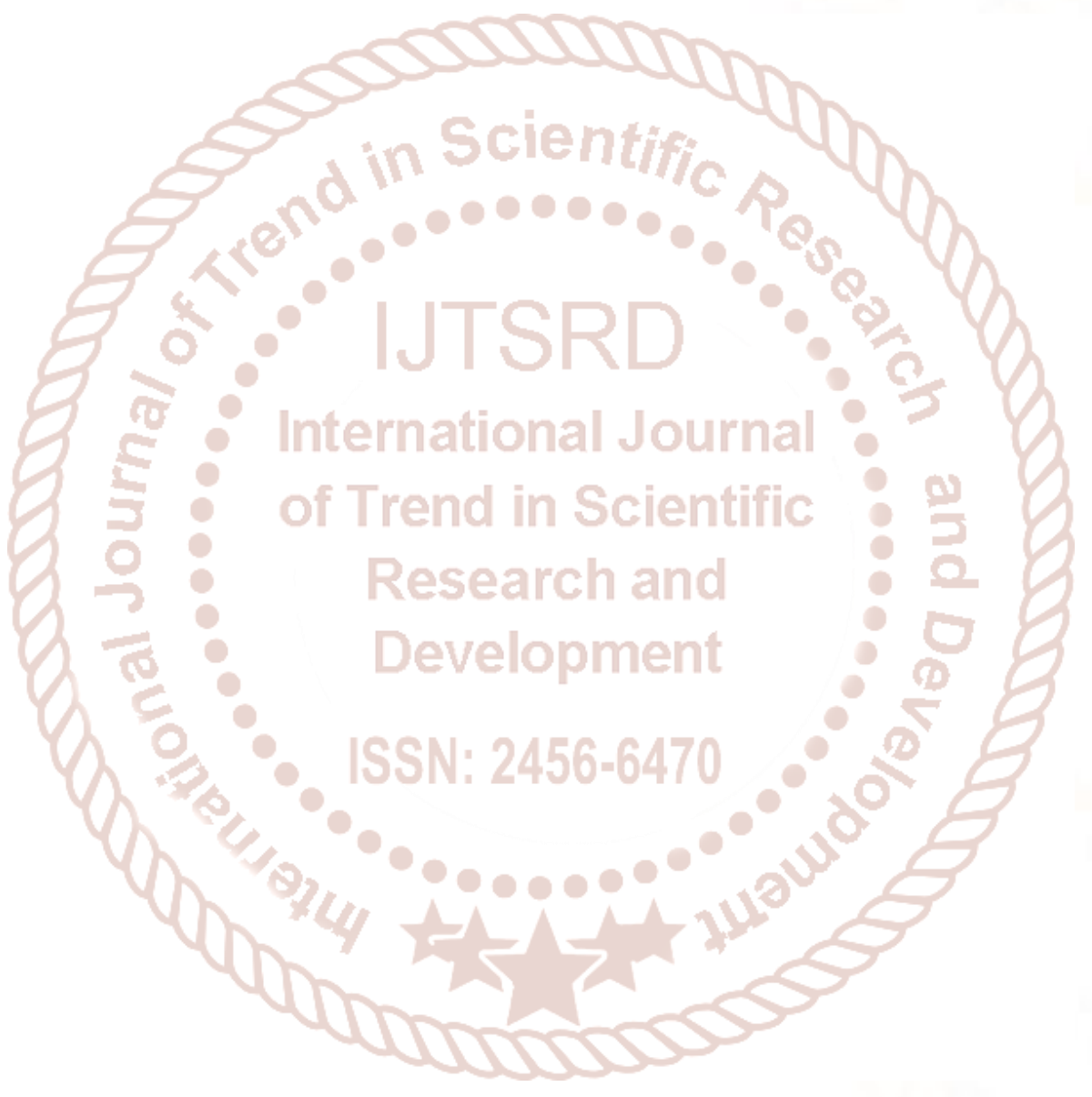

